\title{
Neuronal projections from the Haller's organ and palp sensilla to the synganglion of Amblyomma americanum ${ }^{\mathfrak{s}}$
}

\author{
Projeçôes neuronais do órgão de Haller e sensila palpal até o singânglio de Amblyomma americanum \\ Lígia Miranda Ferreira Borges ${ }^{1 * *}$; Andrew Yongsheng Li ${ }^{2 \dagger}$; Pia Untalan Olafson ${ }^{3}$; Robert Renthal ${ }^{4}$; \\ Gary Roy Bauchan'; Kimberly Hutchison Lohmeyer ${ }^{3}$; Adalberto Angel Pérez de León ${ }^{3}$

\begin{abstract}
${ }^{1}$ Departamento de Microbiologia, Imunologia, Parasitologia e Patologia, Instituto de Patologia Tropical e Saúde Pública, Universidade Federal de Goiás - UFG, Goiânia, GO, Brasil

${ }^{2}$ Invasive Insect Biocontrol \& Behavior Laboratory, United States Department of Agriculture, Agriculture Research Service, Beltsville, MD, U.S.A.

${ }^{3}$ Knipling-Bushland U.S. Livestock Insects Research Laboratory, States Department of Agriculture, Veterinary Pest Genomics Center, Agriculture Research Service, Kerrville, TX, U.S.A.

${ }^{4}$ Deparment of Biology, University Texas at San Antonio, San Antonio, TX, U.S.A.

${ }^{5}$ Electron \& Confocal Microscopy Unit, United States Department of Agriculture, Agriculture Research Service, Beltsville, MD,
\end{abstract} \\ U.S.A.
}

Received March 11, 2016

Accepted April 11, 2016

\begin{abstract}
The present study was conducted to elucidate the neuronal pathways between peripheral olfactory and taste sensilla and the synganglion in an Ixodidae tick species. The tarsus of the front legs (olfactory nerves) and the fourth palpal segment (gustatory nerves) of unfed Amblyomma americanum males and females were excised. A neuronal tracer, dextran tetramethylrhodamine, was used for filling of the sensory neurons. The synganglion preparations were examined using a confocal microscope. Neuronal arborizations from the Haller's organ were confined to the olfactory lobes and the first pedal ganglion. The estimated number of olfactory glomeruli ranged from 16 to 22 per olfactory lobe in the females. The number of glomeruli was not counted in males because they were densely packed. Sensory neurons associated with sensilla at the distal end of the palpal organ projected into the palpal ganglion in the synganglion through the palpal nerve. Gustatory sensory neurons associated with palpal sensilla projected into a commissure with several bulges, which are confined in the palpal ganglion. The findings of distinct projection patterns of sensory neurons associated with the Haller's organ and palpal organ in the lone star tick from this study advanced our knowledge on mechanisms of sensory information processing in ticks.
\end{abstract}

Keywords: Chemical sensilla, neuronal projection, synganglion, Amblyomma americanum.

\section{Resumo}

O presente estudo foi conduzido para elucidar a trajetória neuronal, entre as sensilas periféricas olfativas e gustativas e o singânglio, em uma espécie de carrapato Ixodidae. $\mathrm{O}$ tarso da primeira pata (nervos olfativos) e o quarto segmento palpal (nervos gustativos) de machos e fêmeas não alimentados de Amblyomma americanum foram excisados. Um traçador neuronal, dextran tetrametilrodamina, foi usado para preenchimento dos neurônios sensoriais. Os singânglios foram examinados através de microscopia confocal. Arborizaçóes neuronais do órgão de Haller foram confinadas nos lobos olfativos e primeiro gânglio pedal. O número estimado de glomérulos olfativos variou de 16 a 22 por lobo olfativo nas fêmeas. Em machos, o número de glomérulos não foi contado, pois eles estavam densamente compactados. Os neurônios sensoriais associados com as sensilas, na porção distal do órgáo palpal, projetaram-se no no gânglio palpal do singânglio

\footnotetext{
$\$$ This article reports the results of research only. Mention of a proprietary product does not constitute an endorsement or a recommendation by the USDA for its use. The USDA is an equal opportunity provider and employer.

$\dagger$ Authors contributed equally.

*Corresponding author: Lígia Miranda Ferreira Borges. Departamento de Microbiologia, Imunologia, Parasitologia e Patologia, Instituto de Patologia Tropical e Saúde Pública, Universidade Federal de Goiás - UFG, Rua 235, s/n, Setor Universitário, CEP 74605-050, Goiânia, GO, Brasil. e-mail: ligia@ufg.br
} 
através do nervo palpal. Neurônios sensoriais gustativos associados com a sensila palpal projetaram-se numa comissura onde havia vários bulbos. Os resultados obtidos neste estudo de padróes de projeção distintos de neurônios sensoriais associados com os órgãos de Haller e palpal no carrapato $A$. americanum avançam nosso conhecimento sobre os mecanismos de processamento da informação sensorial em carrapatos.

Palavras-chave: Sensilas químicas, projeção neuronal, singânglio, Amblyomma americanum.

\section{Introduction}

Global climate change is increasing the complexity of the problem with ticks and tick-borne diseases (PÉREZ DE LEÓN et al., 2012; DANTAS-TORRES, 2015; MOYER, 2015). Research efforts that emphasize the development of more effective repellents, attractants, and novel host-targeted and pheromone assisted acaricides are proposed to find sustainable tick control solutions in the United States (BEARD \& STRICKMAN, 2014; ESA, 2015). Ticks use sensory biosystems to detect environmental chemical cues (GUERIN et al., 2000; SONENSHINE \& ROE, 2014), and these forms of communication play a dominant role in regulating behavioral adaptations of ticks to the environment, as well as mediating mating and host localization (SONENSHINE et al., 1986; SONENSHINE, 2006).

Tick olfactory receptors reside mainly in the Haller's organ that is located on the dorsal surface of tarsus I of both forelegs and these receptors detect volatile molecules (HAGGART \& DAVIS, 1980; STEULLET \& GUERIN, 1992; STEULLET \& GNERIN, 1994a, b; LEONOVICH, 2004; SOARES \& BORGES, 2012). Taste receptors are present in the distal segment of the palps and chelicerae, and the tip of tarsus I on the legs. These taste receptors detect non-volatile compounds (WALADDE \& RICE, 1977; WALADDE, 1982; WALADDE \& RICE, 1982; TAYLOR et al., 1991; GRENACHER et al., 2001; SOARES et al., 2013; FERREIRA et al., 2015). Ticks integrate the sensory information received by olfactory and taste receptors and transmit these to the synganglion, which is the tick's central nervous system.

The general anatomical structures of the central nervous system have been described for several tick species (OBENCHAIN \& OLIVER, 1976; MARZOUK et al., 1987; EL SHOURA, 1986; PRULLAGE et al., 1992; ROMA et al., 2012; SONENSHINE \& ROE, 2014). In Argas persicus, the sensory projections of taste sensilla, located in the distal segment of the palp, extend to the subesophageal and palpal glanglia (SRIDHARAN et al., 1998). Studies to characterize the anatomy of the neural system assist in defining how sensory information is processed at the tick synganglion, and this could be used to develop new tick control technologies. However, only limited studies have been done on the anatomical basis of how olfactory and taste information generated by peripheral receptors is integrated in the tick's central nervous system.

Determining the organization of olfactory and gustatory centers in the synganglion is required for understanding how chemosensory information is encoded by ticks. In insects, functional studies using optical imaging methods showed that odors are encoded as specific space-time patterns of glomerular activation, often with multiple glomeruli responding to a particular chemical component (JOERGES et al., 1997; MEIJERINK et al., 2003).
Particularly with medically important insects, three-dimensional maps of glomeruli within the antennal lobes were established using various models (IGNELL et al., 2005; GHANINIA et al., 2007; BARROZO et al., 2009).

The lone star tick, Amblyomma americanum, has a wide host range and is a vector of bacterial and viral pathogens that impact human and animal health (CHILDS \& PADDOCK, 2003; GODDARD \& VARELA-STOKES, 2009). Hummel et al. (2007) reported serotoninergic neuronal processes surrounding the glomeruli in the olfactory lobes of the lone star tick backfilled from a cut in the first leg at the Haller's organ. Here, we describe the neuronal projections from the Haller's organ and palp sensilla to the synganglion of the lone star tick.

\section{Methods}

\section{Ticks}

Unfed adult female and male lone star ticks were obtained from an in vitro colony at the USDA, ARS, Knipling-Bushland US Livestock Insects Research Laboratory in Kerrville, Texas. All unfed adult ticks were maintained in an aquarium held at $27 \pm 2{ }^{\circ} \mathrm{C}, 14: 10$ light: dark cycle and sustained at $85 \%$ relative humidity using a saturated salt solution.

\section{Anterograde filling of the olfactory and taste receptor neurons with neuronal tracer}

Ticks were immobilized on double-sided sticky tape and their legs fixed with sticky tape strips. To access leg nerves that contain neuronal processes associated with olfactory receptors, ticks were fixed dorsally and tarsus I was excised through a cut using a scalpel immediately posterior to the Haller's organ. Ticks were fixed ventrally to excise the 4th palpal segment and access the nerves that contain neurons associated with taste receptors on the palps. Excised samples were placed in a cavity made in a block of wax (Heraeus Kulzer, Armonk, NY, USA), and treated with a drop of deionized water for 30s. The water was removed by wicking away the water using an absorbent tissue and replaced with a drop of $1 \%$ dextran tetramethylrhodamine (TMR 3000 MW; Vector Laboratories, Inc. CA, USA) in deionized water. Subsequently, the end of the tarsus I or palp that was excised was covered with Vaseline to prevent evaporation. The preparation was then placed in a Petri dish containing a damp tissue and maintained at $4^{\circ} \mathrm{C}$ for 48 hours to allow diffusion of the TMR through the nerves to the synganglion.

Preparations of the tick nervous system were dissected in saline (PBS 20X). The synganglion stained with TMR was then fixed in 
$4 \%$ paraformaldehyde in normal saline at $4{ }^{\circ} \mathrm{C}$ for 12 hours. After fixation, each preparation was washed six times, for an hour each time, in saline and triton X-100 on a shaker in the dark. It was then dehydrated in alcohol series (40\%, 60\%, 80\% and 100\% - twice) for $15 \mathrm{~min}$ under stirring and in the dark. The preparation was mounted and clarified in Vectashield medium (Vectashield ${ }^{\circledR}$ ) for 30 min and then visualized using an Olympus BX60 fluorescence microscope (Olympus America Incorporated, Center Valley, PA) to confirm filling from the peripheral neurons to the synganglion.

\section{Microscopy}

A general view of the olfactory and palpal projections was obtained using a Zeiss 710 confocal laser scanning microscope (CLSM) system (Carl Zeiss, Thornwood, NY) equipped with an Argon laser 488 and a $561 \mathrm{~nm}$ Diode laser with a pinhole aperture of $51 \mathrm{~nm}$, using C-Apochromat 10x/0.45 and 63x/1.4 oil immersion Plan Apochromate objectives. To enumerate the glomeruli, the synganglion preparations were analyzed using a Zeiss 710 CLSM system (Carl Zeiss, Thornwood, NY) equipped with an Helium-Neon laser with a pinhole aperture of $37 \mu \mathrm{m}$. Projection sites in the synganglion were scanned using a Plan-Apochromat $20 \mathrm{x} / 0.8 \mathrm{x}$ objective. Z-Stakcs were obtained at $1.0 \mu \mathrm{m}$ intervals from ventral to dorsal side of the synganglion.

The imaging analysis software, Zeiss Zen 2012 Black (Thornwood, NY) was used to analyze the images and produce three-dimensional (3D) images which were converted to maximum intensity projections to generate the $2 \mathrm{D}$ images. Glomeruli in each olfactory lobe were enumerated by tracing the edges of each glomerulus in successive optical sessions using the "Reconstruct" software (http://synapses. clm.utexas.edu/tools/reconstruct/reconstruct.stm).

\section{Results}

Fourteen of 20 synganglia, five from females and nine from males, were successfully backfilled with TMR from the excision site near the Haller's organ. Only four of nine males and three females in 13 were projected retrogradely from the palps stained with TMR.

Neuronal projections originating from olfactory sensilla associated with the Haller's organ were confined primarily to the olfactory lobe and the first pedal ganglia (Figures 1, 2A). Olfactory sensory neurons were traced to the synganglion via the left and right pedal nerve, reaching the olfactory lobe and branching out to innervate individual glomeruli (Figures 3, 4).

The five best olfactory lobes from females were used to identify distinct glomeruli in each preparation, which enabled the enumeration of these glomeruli. The number of glomeruli was estimated at between 16 and 22 per olfactory lobe. The size or volume of the glomeruli was not determined.

Five male synganglion preparations were analyzed by the CLSM system. The glomeruli in the olfactory lobes were densely packed (Figures 4). Thus it was difficult to visualize individual glomeruli. Although it was not possible to separate glomeruli and accurately count or identify them, they appeared to be similar in size to the female olfactory lobes. Macroglomeruli were not observed in the synganglion of either male or female ticks.

Figures 1 and 2B show the backfill of neurons associated with taste receptor(s) located at the distal segment of the palps. The central projections from the olfactory neurons associated with the Haller's organ and taste neurons from the distal segment of the palps do not overlap in the synganglion as shown in Figure 2C, which is a merged image of Figures $2 \mathrm{~A}$ and $2 \mathrm{~B}$. Therefore, it appears that palpal nerves projected only to the palpal ganglion and did not extend to the olfactory lobe. Two palpal projections were observed (Figure 2B, Figure 5) in all synganglion preparation examined. The superior projection extended to a commissure with several clusters of irregular bulges, indicating terminal structures of the sensory neurons.

\section{Discussion}

This study confirms that $A$. americanum olfactory sensilla project into olfactory lobes that, according to Prullage et al. (1992) are paired structures containing numerous and dense clusters that reside beneath the ventral surface of the ventral neuropile pedal ganglia I and commissures connecting the pedals ganglia I and II. Further, the current work describes sensory neurons of the taste sensilla associated with the palpal organ of $A$. americanum that project into the palpal ganglion and do not extend to the olfactory lobes.

In Insecta, olfactory receptor neurons from the antennae and in some cases from the mouthparts, convey chemical information

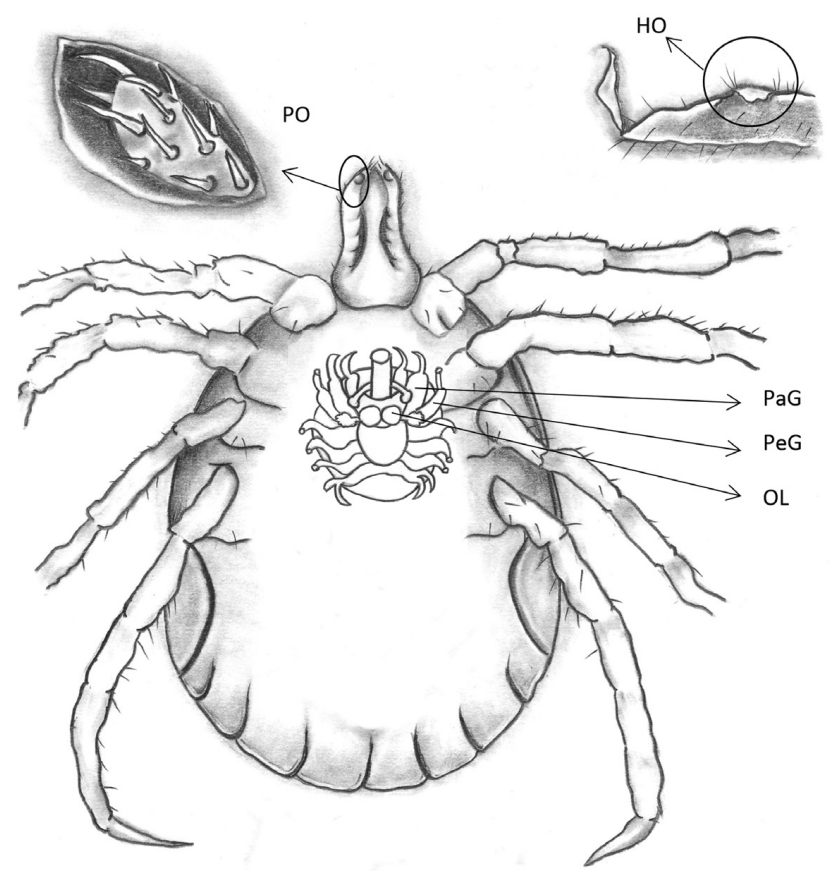

Figure 1. Drawing of adult tick highlighting: - palpal organ (PO) where neuronal projections were observed to reach the palpal ganglion $(\mathrm{PaG})$; and Haller's organ $(\mathrm{HO})$ where neuronal projections extending to pedal I ganglion (PeG) were observed to reach the olfactory Lobe $(\mathrm{OL})$ in the synganglion. Drawing by Eliane Quintais. 

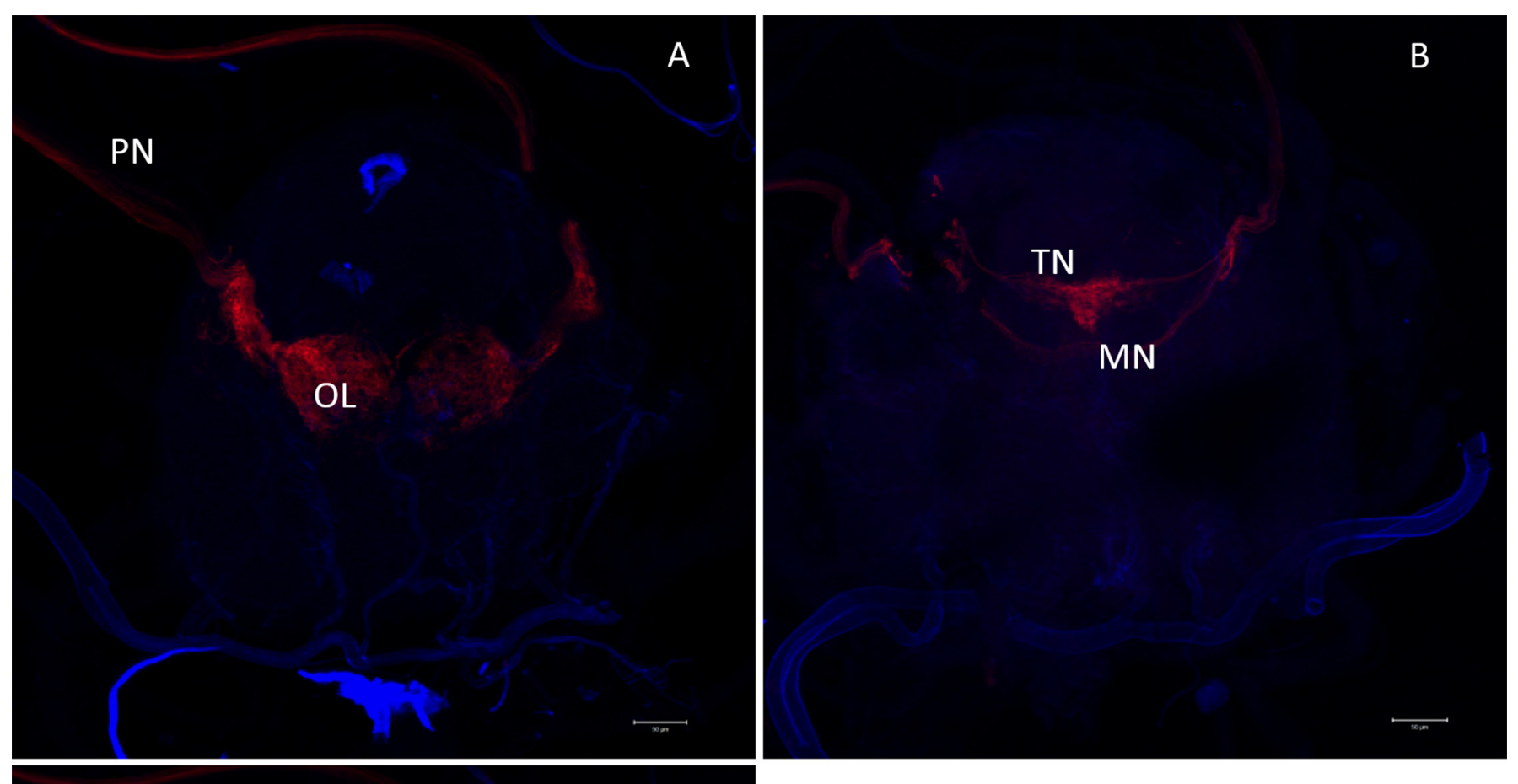

OL

Figure 2. Confocal laser scanning microscopy (CLSM) of synganglion in adult males of Amblyomma americanum that were backfilled with fluorescent neuronal tracer, Dextran tetramethylrhodamine. (A) Olfactory neuron projection from the Haller's organ confined to the olfactory lobes and the first pedal ganglion. (B) Taste neuron projection from palpal organ which projected into the palpal ganglion in the synganglion through the palpal nerve. (C) Merging of A and B to show relative positions of those two type of sensory projections showing distinct projection patterns of sensory neurons associated with the Haller's organ and palpal organ. Motor neuron - MN, Olfactory Lobe - OL, Pedal Nerve PN, Taste Neurons - TN. Bar $=50 \mu \mathrm{m}$.

into the primary olfactory centre of the insect brain, the antennal lobe (ANTON \& HOMBERG, 1999), producing internal representations of the odours' signals detected at the peripheral level. As observed in the present study and in another Acari species (Phytoseiulus persimilis), olfactory afferents from Haller's organ project into an orthologous region in the central nervous system called the olfactory lobe (VAN WIJK et al., 2006). This observation suggests that the organization of the olfactory system is conserved in different arthropod lineages.

The number of glomeruli counted in females of $A$. americanum was estimated at between 16 to 21 , which is similar to the number $(14-21)$ observed in a mite species, Phytoseiulus persimilis (VAN 


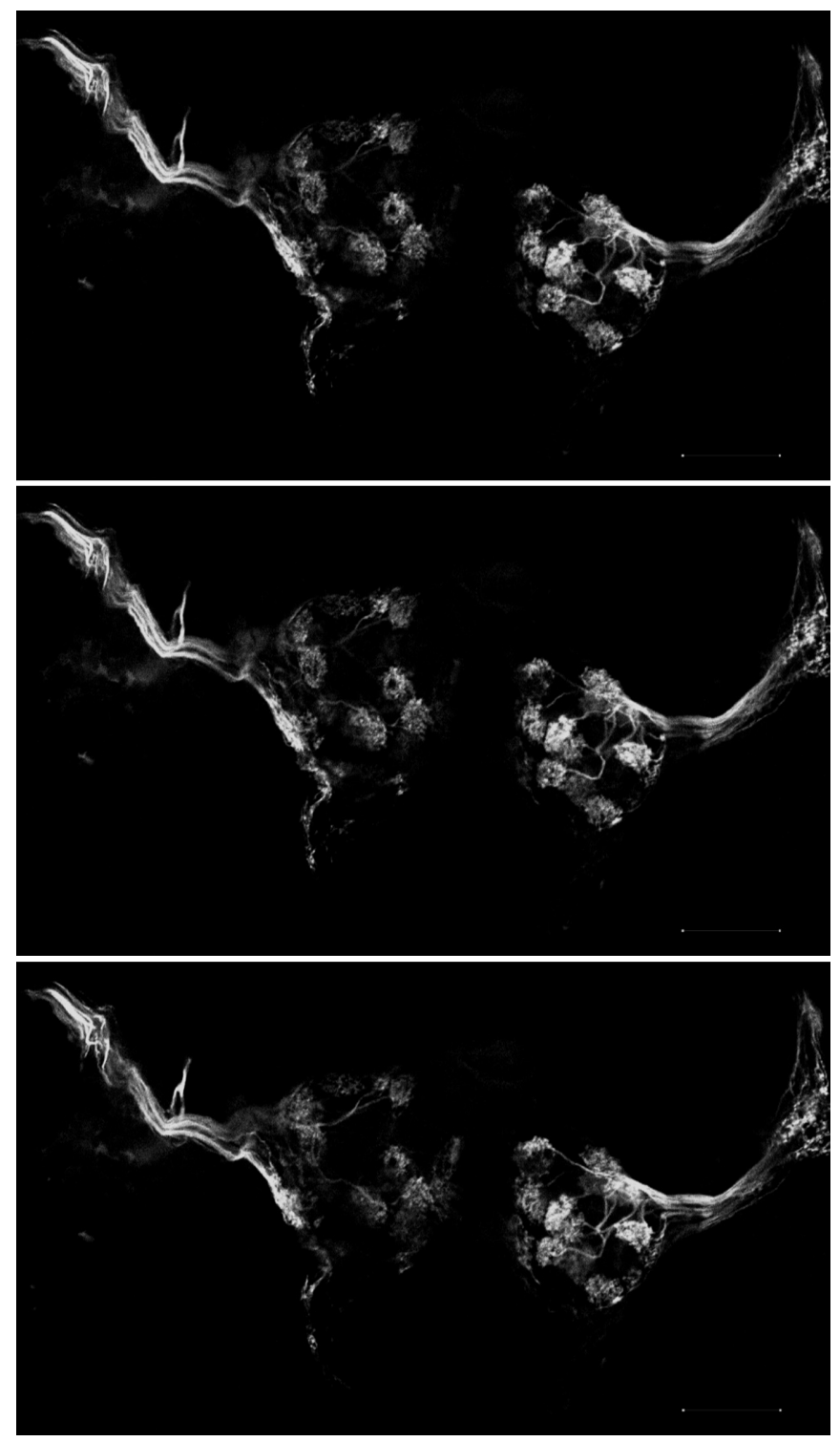

Figure 3. Different CLSM sections of the right and left olfactory lobes in the synganglion of a female Amblyomma americanum stained with Dextran tetramethylrhodamine. Bar $=50 \mu \mathrm{m}$.

WIJK et al., 2006). However, this number was lower than that observed in species of parasitic insects such as Rhodnius prolixus, 28 (BARROZO et al., 2009), Aedes aegypti, 50 (IGNELL et al., 2005), and Anopheles gambiae, 60 (GHANINIA et al., 2007), and it was much lower than that observed in bees, 160 and ants, 215-460 (GALIZIA et al., 1999; SMID et al., 2003; NISHIKAWA et al., 2008; ZUBE et al., 2008). The number of glomeruli is generally considered to be correlated with the number of olfactory receptor neurons, which in turn determines the complexity of odors an arthropod can discriminate. Thus, it appears that arthropod species utilizing a greater variety of chemical signals have a larger number of glomeruli (GALIZIA et al., 1999; KLEINEIDAM et al., 2005). What we found in this study suggests that ticks detect a smaller repertoire of chemical signals than that of social insects and other hematophagous insects. The number of glomeruli in
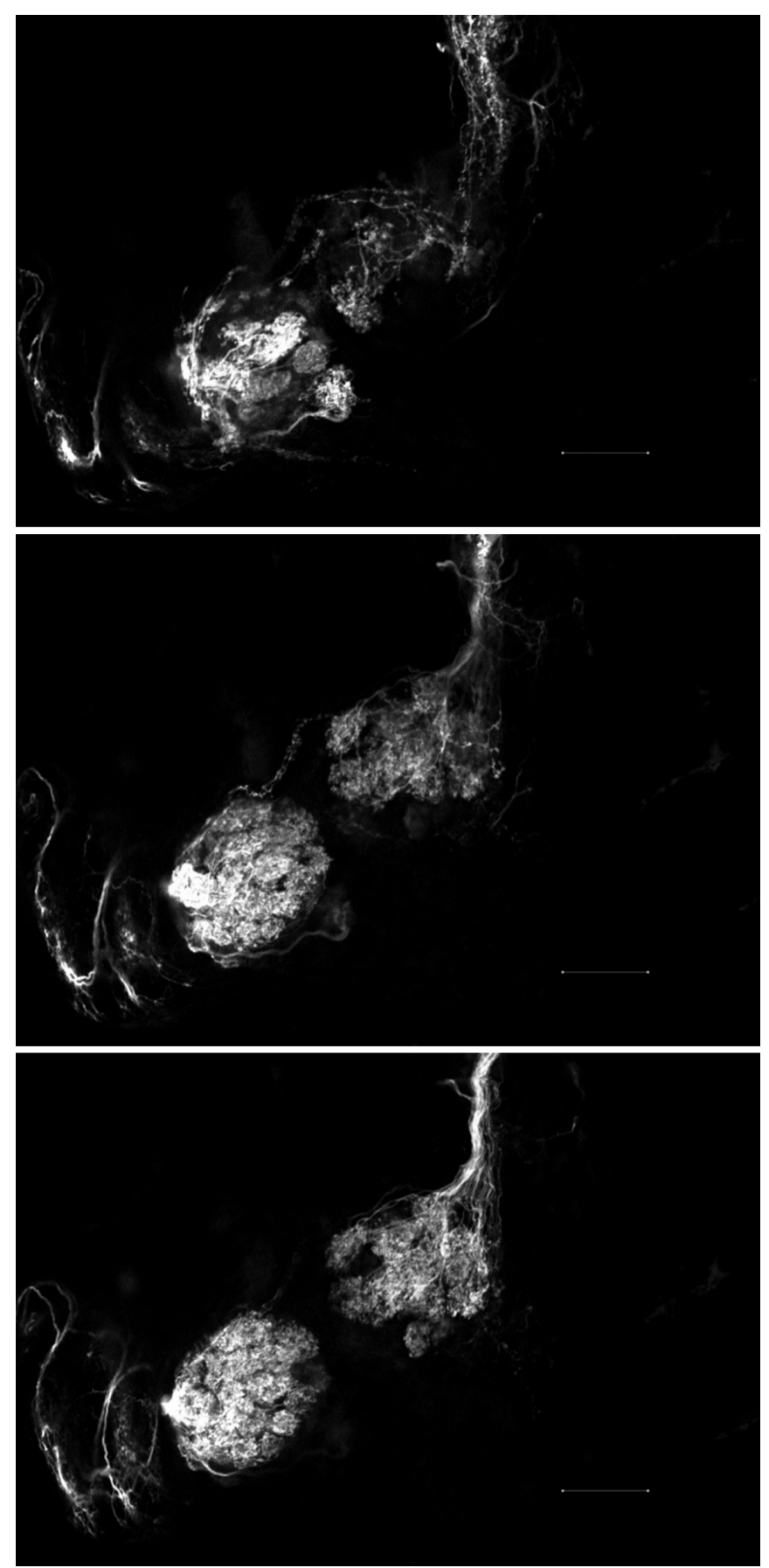

Figure 4. Different CLSM sections of the right and left olfactory lobes in the synganglion of a male Amblyomma americanum stained with tetramethylrhodamine. Bar $=50 \mu \mathrm{m}$. Note that glomeruli from males are more packed than in females.

synganglion preparations of male $A$. americanum was difficult to determine because of the intensity of neuronal staining. Similar limitations have also been observed in Drosophila melanogaster (STOCKER et al., 1990; LAISSUE et al., 1999) and bees, Apis mellifera (GALIZIA et al., 1999). It is possible that the use of other neuronal staining techniques could yield better results.

Josek (2015) used scanning electron microscopy to study the morphology of the Haller's organ in three species of ticks, 


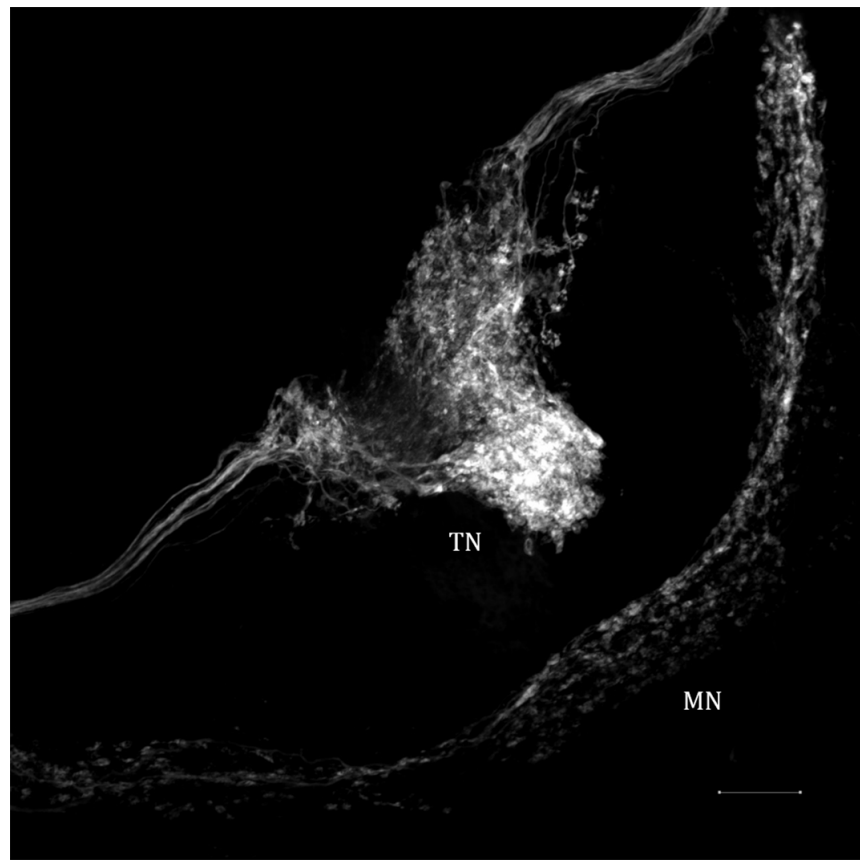

Figure 5. 2D maximum intensity projection of sensory neurons associated with palpal organ in the synganglion of a male Amblyomma americanum showing several bulges. Motor neuron - MN, Taste Neurons - TN. Bar $=20 \mu \mathrm{m}$.

including A. americanum, and observed morphological differences in the Haller's organ between male and female ticks. Even though we were unable to count the number of glomeruli in male preparations, we observed that male glomeruli were more compressed than those of females. Again, this difference might be a reflection of a true difference in the organization of periphery sensory receptors (JOSEK, 2015), or it can simply be an artifact of the staining technique. Although we cannot say whether the number and organization of glomeruli are sexually dimorphic in A. americanum, it is clear that males do not exhibit increased glomeruli. Macroglumeruli have been described in the olfactory lobes of moths, cockroaches, and bees (ANTON \& HOMBERG, 1999) and are believed to play a role in receiving information from olfactory receptor neurons that detect sex pheromones from distance. Ticks, including $A$. americanum, use sex pheromones to attract mates from short distances (BERGER, 1972). This may explain the lack of macroglomeruli in tick olfactory lobes. The absence of increased glomeruli was also observed in A. aegypti (IGNELL et al., 2005) and $R$. prolixus (BARROZO et al., 2009).

Nymphs and adults of $A$. variegatum, a related three-host tick, have 19 olfactory sensilla encompassing between 68 and 94 putative olfactory receptors per tarsus (HESS \& VLIMANT, 1982). Assuming that the number of olfactory receptors in A. americanum is similar to that observed in $A$. variegatum, and considering we counted 16 to 21 glomeruli, it can be hypothesized that each glomerulus is innervated by approximately four afferent neurons. This number is considerably lower than that observed in insects (ANTON \& HOMBERG, 1999; IGNELL et al., 2005), but higher than that observed in the predatory mite $P$. persimilis in which the number of sensory receptor neurons is the same as the number of glomeruli (VAN WIJK et al., 2006).

While maintaining the basic principles of cellular organization, different insect groups show large differences in the morphology of the antennal lobe. The antennal lobes contain two major classes of neurons: multiglomerulus neurons whose processes invade several glomeruli, or uniglomerulus neurons that invade a single glomerulus (HANSSON \& ANTON, 2000), as we observed here for the ixodid tick.

Palpal backfill preparations of $A$. americanum resulted in two neuronal projection tracks to the synganglion. One of the two tracks may be the projection of taste neurons and the other the motor neurons. In Argas persicus, Sridharan et al. (1998) backfilled palpal sensilla with cobalt-dye. Just as in A. americanum, they found that a projection is extended in a commissure to the contralateral side in the anteriormost region of the suboesophageal ganglion. Together, these data suggest that Argasidae and Ixodidae ticks share a similar neuronal organization and neural mechanisms for perceiving and processing sensory information. Restriction of neuronal projections from $A$. americanum palps to the palpal ganglion, and not to the olfactory lobes, was also observed in the predatory mite $P$. persimilis (VAN WIJK et al., 2006). The IV palpal segment in ticks houses the palpal organ, and data from the current study indicate that the organ likely does not have an olfactory function. Further, A. americanum nymphs have 10 sensilla, nine of which contain two mechanoreceptor dendrites plus several ( 4 to 12 ) chemosensory receptors dendrites (FOELIX \& WANG, 1972). In contrast, maxillary palp neurons in mosquitoes project to the antennal lobe, and there are odorant receptors present in this organ (ANTON \& ROSPARS, 2004; IGNELL et al., 2005).

Results from the current study on central projection of olfactory and taste neurons in the synganglion contribute to our understanding of central processing of olfactory and gustatory information by ticks. We are currently assessing alternative neuron labeling techniques to develop a 3D reconstruction of glomeruli in tick olfactory lobes in the tick central nervous system. We are also evaluating backfills from single sensory sensilla to visualize the projection pattern of individual sensory receptor neurons.

\section{Acknowledgements}

We thank Dr. Erika Machtinger (USDA, ARS, IIBBL) for review of the manuscript, and Jason Tidwell (USDA, ARS, KBUSLIRL) for technical assistance with tick dissections. This research was supported by a Post-Doctorate Scholarship from Science without Borders Program - CNPq (200459/2014-7), with funds from USDA-ARS appropriated project 3094-32000-03900 , and by a grant to the University of Texas at San Antonio from the National Institute on Minority Health and Health Disparities (G12MD007591).

\section{References}

Anton S, Homberg U. Antennal lobe structure. In: Hansson BS. Insect olfaction. Berlin: Springer; 1999. p. 97-124. http://dx.doi.org/10.1007/9783-662-07911-9_5. 
Anton S, Rospars JP. Quantitative analysis of olfactory receptor neuron projections in the antennal lobe of the malaria mosquito, Anopheles gambiae. J Comp Neurol 2004; 475(3):315-326. http://dx.doi.org/10.1002/ cne.20174. PMid:15221948.

Barrozo RB, Couton L, Lazzari CR, Insausti TC, Minoli SA, Fresquet $\mathrm{N}$, et al. Antennal pathways in the central nervous system of a bloodsucking bug, Rhodnius prolixus. Arthropod Struct Dev 2009; 38(2): 101110. http://dx.doi.org/10.1016/j.asd.2008.08.004. PMid:18809510.

Beard CB, Strickman D. Federal initiative: tick-borne disease integrated pest management white paper [online]. Washington: EPA; 2014 [cited 2015 Oct 3]. Available from: http://www.epa.gov/pestwise/ticks/tickipm-whitepaper.pdf

Berger RS. 2,6-dichlorophenol, sex pheromone of the lone star tick. Science 1972; 177(4050): 704-705. http://dx.doi.org/10.1126/ science.177.4050.704. PMid:5054146.

Childs JE, Paddock CD. The ascendancy of Amblyomma americanum as a vector of pathogens affecting humans in the United States. Annu Rev Entomol 2003; 48(1): 307-337. http://dx.doi.org/10.1146/annurev. ento.48.091801.112728. PMid:12414740.

Dantas-Torres F. Climate change, biodiversity, ticks and tick-borne diseases: the butterfly effect. Int J Parasitol Parasites Wildl 2015; 4(3): 452-461. http://dx.doi.org/10.1016/j.ijppaw.2015.07.001. PMid:26835253.

El Shoura SM. Fine structure of the synganglion of Ornithodoros (Pavlovskyella) erraticus (Ixodoidea: Argasidae). Acarologia 1986; 27(4): 295-302.

Entomological Society of America - ESA. Position statement on tickborne diseases [online]. Annapolis: ESA; 2015. [cited 2015 Oct 3]. Available from: http://www.entsoc.org/PDF/2015/ESA-PolicyStatementTickBorneDiseases.pdf

Ferreira LL, Soares SF, Oliveira JG Fo, Oliveira TT, Pérez de León AA, Borges LMF. Role of Rhipicephalus microplus cheliceral receptors in gustation and host differentiation. Ticks Tick Borne Dis 2015; 6(3): 228233. http://dx.doi.org/10.1016/j.ttbdis.2014.12.008. PMid:25616714.

Foelix RF, Wang IWC. Fine structural analysis of palpal receptors in the tick Amblyomma americanum (L.). Z Zellforsch 1972; 129(4): 548-560. http://dx.doi.org/10.1007/BF00316749. PMid:5042252.

Galizia CG, McIlwrath SL, Menzel R. A digital three-dimensional atlas of the honeybee antennal lobe based on optical sections acquired by confocal microscopy. Cell Tissue Res 1999; 295(3): 383-394. http:// dx.doi.org/10.1007/s004410051245. PMid:10022959.

Ghaninia M, Hansson BS, Ignell R. The antennal lobe of the African malaria mosquito, Anopheles gambiae, innervation and three-dimensional reconstruction. Arthropod Struct Dev 2007; 36(1): 23-39. http://dx.doi. org/10.1016/j.asd.2006.06.004. PMid:18089085.

Goddard J, Varela-Stokes AS. Role of the lone star tick, Amblyomma americanum (L.), in human and animal diseases. Vet Parasitol 2009; 160(1-2): 1-12. http://dx.doi.org/10.1016/j.vetpar.2008.10.089. PMid:19054615.

Grenacher S, Kröber T, Guerin PM, Vlimant M. Behavioural and chemoreceptor cell responses of the tick, Ixodes ricinus, to its own faeces and faecal constituents. Exp Appl Acarol 2001; 25(8): 641-660. http:// dx.doi.org/10.1023/A:1016145805759. PMid:12171273.

Guerin PM, Kröber T, McMahon C, Guerenstein P, Grenacher S, Vlimant $\mathrm{M}$, et al. Chemosensory and behavioural adaptations of ectoparasitic arthropods. Nova Acta Leopold 2000; 83(316): 213-229.
Haggart DA, Davis EE. Ammonia-sensitive neurones on the first tarsi of the tick, Rhipicephalus sanguineus. J Insect Physiol 1980; 26(8): 517-523. http://dx.doi.org/10.1016/0022-1910(80)90126-2.

Hansson BS, Anton S. Function and morphology of the antennal lobe: new developments. Annu Rev Entomol 2000; 45(1): 203-231. http:// dx.doi.org/10.1146/annurev.ento.45.1.203. PMid:10761576.

Hess E, Vlimant M. The tarsal sensory system of Amblyomma variegatum Fabricius (Ixodidae, Metastriata). I. Wall pore and terminal pore sensilla. Rev Suisse Zool 1982; 89: 713-729. http://dx.doi.org/10.5962/bhl.part.82470.

Hummel NA, Li AY, Witt CM. Serotonin-like immunoreactivity in the central nervous system of two ixodid tick species. Exp Appl Acarol 2007; 43(4): 265-278. http://dx.doi.org/10.1007/s10493-007-9120-z. PMid:18040871.

Ignell R, Dekker T, Ghaninia M, Hansson BS. Neuronal architecture of the mosquito deutocerebrum. J Comp Neurol 2005; 493(2): 207-240. http://dx.doi.org/10.1002/cne.20800. PMid:16255032.

Joerges J, Küttner A, Galizia CG, Menzel R. Representations of odours and odour mixtures visualized in the honeybee brain. Nature 1997; 387: 285-288.

Josek T. A deeper look into the morphology and receptors found in the tick (Acari: Ixodidae) chemoperception structure, the Haller's organ. [Thesis]. Illinois: University of Illinois at Urbana-Champaign; 2015 [cited 2015 Oct 3]. Available from: http://hdl.handle.net/2142/88299

Kleineidam CJ, Obermayer M, Halbich W, Rossler W. A macroglomerulus in the antennal lobe of leaf-cutting ant workers and its possible functional significance. Chem Senses 2005; 30(5): 383-392. http://dx.doi.org/10.1093/ chemse/bji033. PMid:15843501.

Laissue PP, Reiter C, Hiesinger PR, Halter S, Fischbach KF, Stocker RF. Three-dimensional reconstruction of the antennal lobe in Drosophila melanogaster. J Comp Neurol 1999; 405(4): 543-552. http:// dx.doi.org/10.1002/(SICI)1096-9861(19990322)405:4<543::AIDCNE7>3.0.CO;2-A. PMid:10098944.

Leonovich SA. Phenol and lactone receptors in the distal sensilla of the Haller's organ in Ixodes ricinus ticks and their possible role in host perception. Exp Appl Acarol 2004; 32(1-2): 89-102. http://dx.doi. org/10.1023/B:APPA.0000018200.24760.78. PMid:15139275.

Marzouk AS, Khalil GM, Mohamed FSA, Farid N. Hyalomma dromedarii (Acari: Ixodoidea: Ixodidae): central and peripheral nervous system anatomy. ExpAppl 1987; 3(2): 145-161. http://dx.doi.org/10.1007/BF01270476.

Meijerink J, Carlsson MA, Hansson BS. Spatial representation of odorant structure in the moth antennal lobe: a study of structure-response relationship at low doses. J Comp Neurol 2003; 467(1): 11-21. http:// dx.doi.org/10.1002/cne.10914. PMid:14574676.

Moyer MW. The growing global battle against blood-sucking ticks. Nature 2015; 524(7566): 406-408. http://dx.doi.org/10.1038/524406a. PMid:26310749.

Nishikawa M, Nishino H, Misaka Y, Kubota M, Tsuji E, Satoji Y, et al. Sexual dimorphism in the antennal lobe of the ant Camponotus japonicus. Zoolog Sci 2008; 25(2): 195-204. http://dx.doi.org/10.2108/zsj.25.195. PMid:18533751.

Obenchain FD, Oliver JH Jr. eripheral nervous system of the ticks, Amblyomma tuberculatum Marx and Argas radiatus Railliet (Acari: Ixodoidea). J Parasitol 1976; 62(5): 811-817. http://dx.doi.org/10.2307/3278965. PMid:978369.

Pérez de León AA, Teel PD, Auclair AN, Messenger MT, Guerrero FD, Schuster G, et al. Integrated strategy for sustainable cattle fever tick 
eradication in USA is required to mitigate the impact of global change. Front Physiol 2012; 3: 195. http://dx.doi.org/10.3389/fphys.2012.00195. PMid:22712018.

Prullage JB, Pound M, Meola SM. Synganglial morphology and neurosecretory centers of adult Amblyomma americanum (L.) (Acari: Ixodidae). J Med Entomol 1992; 29(6): 1023-1034. http://dx.doi. org/10.1093/jmedent/29.6.1023. PMid:1460618.

Roma GC, Nunes PH, Oliveira PR, Medicine RN, Bechara GH, CamargoMathias MI. Central nervous system of Rhipicephalus sanguineus ticks (Acari: Ixodidae): an ultrastructural study. Parasitol Res 2012; 111(3): 1277 1285. http://dx.doi.org/10.1007/s00436-012-2962-2. PMid:22610445.

Smid HM, Bleeker MA, van Loon JJ, Vet LE. Three-dimensional organization of the glomeruli in the antennal lobe of the parasitoid wasps Cotesia glomerata and C. rubecula. Cell Tissue Res 2003; 312(2): 237-248. PMid:12684866.

Soares SF, Borges LMF. Electrophysiological responses of the olfactory receptors of the tick Amblyomma cajennense (Acari: Ixodidae) to hostrelated and tick pheromone-related synthetic compounds. Acta Trop 2012; 124(3): 192-198. http://dx.doi.org/10.1016/j.actatropica.2012.08.007. PMid:22925715.

Soares SF, Louly CCB, Marion-Poll F, Ribeiro MFB, Borges LMF. Study on cheliceral sensilla of the brown dog tick Rhipicephalus sanguineus (Latreille, 1806) (Acari: Ixodidae) involved in taste perception of phagostimulants. Acta Trop 2013; 126(1): 75-83. http://dx.doi.org/10.1016/j. actatropica.2013.01.006. PMid:23352572.

Sonenshine DE, Roe M. Biology of ticks. 2nd ed. New York: Oxford University Press; 2014. vol. 1. 560 p.

Sonenshine DE, Taylor D, Carson KA. Chemically mediated behavior in acari: adaptions for finding hosts and mates. J Chem Ecol 1986; 12(5): 1091-1108. http://dx.doi.org/10.1007/BF01638998. PMid:24307049.

Sonenshine DE. Tick pheromones and their use in tick control. Annu Rev Entomol 2006; 51(1): 557-580. http://dx.doi.org/10.1146/annurev. ento.51.110104.151150. PMid:16332223.

Sridharan TB, Prakash S, Chauhan RS, Rao KM, Singh K, Singh RN. Sensilla on the palps and legs of the adult soft tick Argas persicus Oken (Ixodoidea: Argasidae) and their projections to the central nervous system. Int J Insect Morphol Embryol 1998; 27(4): 273-289. http://dx.doi. org/10.1016/S0020-7322(98)00020-8.
Steullet P, Gnerin PM. Identification of vertebrate volatiles stimulating olfactory receptors on tarsus I of the tick Amblyomma variegatum Fabricius (Ixodidae). I. Receptors within the Haller's organ capsule. J Comp Physiol A Neuroethol Sens Neural Behav Physiol 1994a; 174(1): 27-38. http:// dx.doi.org/10.1007/BF00192003. PMid:8151519.

Steullet P, Gnerin PM. Identification of vertebrate volatiles stimulating olfactory receptors on tarsus I of the tick Amblyomma variegatum Fabricius (Ixodidae). II. Receptors outside the Haller's organ capsule. J Comp Physiol A Neuroethol Sens Neural Behav Physiol 1994b; 174(1): 39-47. http:// dx.doi.org/10.1007/BF00192004

Steullet P, Guerin PM. Perception of breath components by the tropical bont tick, Amblyomma variegatum Fabricius (Ixodidae). II. Sulfide-receptors. J Comp Physiol A Neuroethol Sens Neural Behav Physiol 1992; 170(6): 677-685. http://dx.doi.org/10.1007/BF00198977. PMid:1432848.

Stocker RF, Lienhard MC, Borst A, Fischbach KF. Neuronal architecture of the antennal lobe in Drosophila melanogaster. Cell Tissue Res 1990 262(1): 9-34. http://dx.doi.org/10.1007/BF00327741. PMid:2124174.

Taylor D, Phillips JS, Sonenshine DE, Hanson FE. Ecdysteroids as a component of the genital sex pheromone in two species of hard ticks Dermacentor variabilis and Dermacentor andersoni (Acari: Ixodidae). Exp ApplAcarol 1991; 12(3): 275-296. http://dx.doi.org/10.1007/BF01193473.

Van Wijk M, Wadman JW, Sabelis MW. Morphology of the olfactory system in the predatory mite Phytoseiulus persimilis. Exp Appl Acarol 2006; 40(3-4): 217-229. http://dx.doi.org/10.1007/s10493-006-9038-x. PMid:17245560.

Waladde SM, Rice MJ. The sensory basis of tick feeding behaviour. In: Obenchain FD, Galun R. Physiology of ticks. 1st ed. Oxford: Pergamon; 1982. p. 71-118.

Waladde SM, Rice MJ. The sensory nervous system of the adult cattle tick Boophilus microplus (Canestrini) Ixodidae. Part III. Ultra-structure and electrophysiology of cheliceral receptors. Aust J Entomol 1977; 16(4): 441-453. http://dx.doi.org/10.1111/j.1440-6055.1977.tb00137.x.

Waladde SM. Tip-recording from ixodid tick olfactory sensilla: responses to tick related odors. J Comp Physiol 1982; 148(4): 411-418. http:// dx.doi.org/10.1007/BF00619780.

Zube C, Kleineidam CJ, Kirschner S, Neef J, Rossler W. Organization of the olfactory pathway and odor processing in the antennal lobe of the ant Camponotus floridanus. J Comp Neurol 2008; 506(3): 425-441. http://dx.doi.org/10.1002/cne.21548. PMid:18041786. 